\title{
Assessment of Chemical Pollution With Routine Pesticides Using PRIMET, a Pesticide Risk Model in the Benoe Stream in the South-West Region of Cameroon
}

\section{Daniel Brice Kenko Nkontcheu}

Laboratory for Biology and Applied Ecology, Department of Animal

Biology, Faculty of Science, University of Dschang Zoology Laboratory, Department of Zoology and Animal Physiology,

Faculty of Science, University of Buea

\section{Patricia Bi Asanga Fai}

Laboratory for Biology and Applied Ecology, Department of Animal Biology, Faculty of Science, University of Dschang

\section{Géraud Canis Tasse Taboue}

Laboratory for Biodiversity and Conservation Biology, Department of

Zoology and Animal Physiology, University of Buea

Ore Processing Laboratory, Institute of Geological and Mining Research

\section{Norbert Ngameni Tchamadeu \\ Francis Ngealekeleoh \\ Mpoame Mbida}

Laboratory for Biology and Applied Ecology, Department of Animal

Biology, Faculty of Science, University of Dschang

Doi: 10.19044/esj.2017.v13n30p153 URL:http://dx.doi.org/10.19044/esj.2017.v13n30p153

\begin{abstract}
Widespread extensive and improper application of pesticides may pose risk to aquatic ecosystem and affect non-target organisms. This study aimed at assessing chemical pollution with pesticides using the PRIMET (Pesticides Risks in the tropics to Man, Environment and Trade) model in the Benoe stream. Ecotoxicological data on pesticides, pesticide and water physico-chemistry were used as input parameters. Water parameters were measured monthly for 06 months in 08 sampling points along the stream. Pesticide characteristics were obtained from the Pesticides Properties Data Base (PPDB) and the PRIMET software. The risk assessment was done for 44 active ingredients used in the area and whose ecotoxicological and physico-chemical data were available. Water parameters significantly $(\mathrm{p}<0.05)$ varied across seasons. Based on the Exposure Toxicity Ratio (ETR)
\end{abstract}


and the Predicted Exposure Concentration (PEC), the model predicted 09 pesticides to pose a definite acute risk (ETR>100), seven to pose an acute possible risk $(1 \leq \mathrm{ETR} \leq 100)$ and 28 to pose no risk $(\mathrm{ETR}<1)$. Cadusafos $(\mathrm{ETR}=5200, \mathrm{PEC}=39 \mu \mathrm{g} / \mathrm{l})$ was the most risky pesticide while imazalil $(\mathrm{ETR}=0.0002, \quad \mathrm{PEC}=0.0053 \mu \mathrm{g} / \mathrm{l})$ was the least risky compound. Cypermethrin was predicted to pose both definite acute risk to water and possible chronic risk to fish, water and Daphnia. Seven active ingredients were predicted to pose possible chronic risk to Daphnia. Pesticide used in plantations near water bodies is a threat to the aquatic ecosystem augmented in case of misuse. Bioaccumulation potential and impact of these compounds on water quality and biota community structure should be examined.

Keywords: Risk Assessment, PRIMET, Aquatic, ETR

\section{Introduction}

Exposure of organisms to xenobiotics such as pesticides is a serious environmental and toxicological chemistry matter (Olufayo and Alade, 2012). Pesticides have potential effects on organisms in water, in the soil, on plants and pose a threat to human health via dietary exposure when they consume contaminated ground water, macrophytes and fishes found in internal waters (FAO, 2010a). Risk is the chance, within a time frame, of an adverse event occurring with specific consequences (Pollino et al., 2012). Pesticides are carcinogenic and neurotoxic. Those containing chlorine can cause skin irritation known as chloracne (Chevalier et al., 2003). Due to their toxicity and their constant use throughout the world, pesticides are one of the main factors triggering biodiversity decline. Thousands of pesticides are used worldwide but data on contamination for any particular pesticide are usually quite limited (Bhavika and Pragna, 2014). Risk assessment is a process used to collect, organize, integrate, and analyze information for use in a planning environment, where the outcome is the analysis and prioritization of risks or hazards to a stated objective (Pollino et al., 2012).

In recent years, the interest in using ecological population models as a tool for pesticide risk assessment has increased rapidly (Wang and Grimm, 2010). Despite considerable increased pesticide use over the past decades, little research has been done into their fate and effects in surface waters in tropical regions (Daam and Brink , 2010). In poor countries, the lack of resources is the main hindrance in risk assessment. Qualitative, quantitative or a combination of both models play a key role in risk assessment (Pollino et al., 2012). It is still unclear which endpoint (population density, population growth, etc.) is the most sensitive indicator of population-level effects and how risk can be evaluated at the population level (Wang and Grimm, 2010). PRIMET (Pesticides Risks in the tropics to Man, 
Environment and Trade ) is a simple risk assessment model that requires few inputs and is suitable for use in developing countries (Peteers et al., 2008).This model has been used in two Asian countries (Thailand and Sri Lanka) and in South Africa (Malherbe et al., 2013). PRIMET is able to estimate the risk of pesticides application to aquatic and terrestrial life, earthworms, bees, non-target arthropods, the use of groundwater as drinking water and dietary exposure via the consumption of groundwater, vegetables, fish and macrophytes. It has a wide scope for application, needs a limited number of parameters and is cost-effective, thus making it easy to use even by people without specialized training (Peeters et al., 2008).

The risk posed by pesticides in Cameroon remains unclear as there is almost no comprehensive report existing on pesticide risk assessment in the country. The Benoe Stream (South-West Cameroon) takes its sources in Buea and runs through Mutengene, Tiko and makes its estuary around Bwenga; it is surrounded with small scale farms and Cameroon Development Corporation (CDC) plantations, subjecting it to pollution from urban, municipal and agricultural origin. This study aimed at assessing pesticide risk in the Benoe Stream using the PRIMET model, based on a worse-case scenario. This was done through measurement of water parameters (field and laboratory) and pesticide characteristics (physico-chemical characteristics, ecotoxicological data and application scheme) that were all used as input parameters.

\section{Material and methods}

PRIMET requires two sets of data as input parameters: pesticide characteristics and water characteristics (Peeters et al., 2008).

\section{Pesticides characteristics}

Pesticide characteristics including molecular mass $(\mathrm{g} / \mathrm{mol})$, saturated vapour pressure $(\mathrm{Pa})$, solubility $(\mathrm{mg} / \mathrm{l})$, half-life in water (days), half-life in sediments (days), organic carbon-water partition coefficient $(1 / \mathrm{kg})$ and ecotoxicological data such as LC50-vertebrates (Median Lethal Dose), LC50-invertebrates, LC50-primary producers, NOEC-Fish (No Observable Effect Concentration) and NOEC-Daphnia were obtained from the PRIMET software and the PPDB (Pesticide Properties Data Base) (IUPAC, 2017).

The specific pesticide application schemes practiced by the farmers were determined by survey in terms of dosage, number of applications, and interval between applications. These data are found together with ETR values in tables 4, 5 and 6 . The default \% spray drift in the PRIMET software is $2.77 \%$ and is applicable if the distance to the ditch is $1 \mathrm{~m}$. That value was used as recommended by Peeters et al. (2008) because the stream 
was adjacent to farms. These data have been previously collected for 44 active ingredients commonly used in the area (Kenko et al., 2017).

\section{Water characteristics}

Water physico-chemical parameters were collected over six months (December 2016 to May 2017) in eight sampling points (S1, S2,..,S8) in the Benoe stream along small scale farms and CDC Ndongo and Holthforth farms. Sampling points were chosen based on land use and the location of farms. Surveys were holistic taking into account seasonal variation in the hydrological regime of the stream.

The ambient temperature was measured in situ with a thermometer and values were converted from ${ }^{\circ} \mathrm{C}$ into $\mathrm{K}$ (Kelvin) as required by PRIMET. The amount of suspended solids $(\mathrm{kg} / \mathrm{l})$ and the mass fraction of organic matter in suspended solids $(\mathrm{g} / \mathrm{g})$ were determined using standard methods (Pauwels et al.,1992).Water velocity (V) was determined using the float method (Michaud and Wierenga, 2005). The bottom width (B) and the depth of the canal (h) were determined using a measuring tape and results expressed in meters. The length of the canal (1) was calculated from the GPS coordinates. The side slope was determined as recommended by Van den Brink et al. (2005) and Peeters et al. (2008).

\section{Data processing and analysis}

The aquatic risk assessment of pesticides was carried out using pesticides application rate data, physico-chemical properties parameters of the water body. For each active ingredient, PRIMET calculated the Predicted Exposure Concentration (PEC), the Predicted No Effects Concentration (PNEC) and the Exposure Toxicity Ratio (ETR=PEC/PNEC) (Ansara-Ross et al., 2008). Risk assessment for given pesticide active ingredients was done based on the following ETR categories as proposed by Peeters et al. (2008):

* ETR < 1.......................No Risk

* $1 \leq$ ETR $\leq 100 \ldots . . . . . . . . . .$. Possible Risk

* ETR > 100..................Definite Risk

ANOVA was used to determine if hydrological parameters varied across sampling sites, whereas the t-test was performed to compare the means of these parameters between seasons. Principal Component Analysis (PCA) was used to visualize possibly correlated hydrological variables in a two dimensional plane across sampling points. All statistical analyses were conducted in R 3.4.0 (R Core Team, 2017). 


\section{Results}

\section{Water Hydrology}

The mean values of water parameters $(\mathrm{Mean} \pm \mathrm{SEM})$ are presented in table 1 . Table 2 gives the variation of water parameters in space while table 3 presents seasonal variation in water parameters.

Table 1: Hydrological variables of the Benoe stream

\begin{tabular}{|c|c|c|c|}
\hline Variable & Description & $\mathbf{N}$ & Mean \pm SEM \\
\hline $\mathbf{B}(\mathbf{m})$ & Bottom Width & 48 & $5.28 \pm 0.24$ \\
\hline $\mathbf{H}(\mathbf{m})$ & Depth & 48 & $0.43 \pm 0.03$ \\
\hline $\mathbf{L}(\mathbf{m})$ & Long Profile & 1 & 17284 \\
\hline $\mathbf{M O M}(\mathbf{g} / \mathbf{g})$ & $\begin{array}{c}\text { Mass fraction of organic matter in } \\
\text { suspended solids }\end{array}$ & 48 & $0.07 \pm 0.03$ \\
\hline $\mathbf{S 1}(/)$ & Side Slope & 48 & $1.6 \pm 0.18$ \\
\hline $\mathbf{S S}(\mathbf{k g} / \mathbf{l})$ & $\begin{array}{c}\text { Mass concentration of suspended } \\
\text { solids }\end{array}$ & 48 & $0.001861 \pm 0.000485$ \\
\hline $\mathbf{T}(\mathbf{K})$ & Water temperature & 48 & $299.48 \pm 0.21$ \\
\hline $\mathbf{V}(\mathbf{m} / \mathbf{d})$ & Flow velocity & 48 & $31806 \pm 2918.2$ \\
\hline
\end{tabular}

SEM= Standard Error of Mean $\quad \mathrm{N}=$ Sample Size

Table 2: Variation of hydrological variables means across sampling points

\begin{tabular}{|c|c|c|c|c|c|c|c|c|}
\hline \multirow[t]{2}{*}{ Var. } & \multicolumn{8}{|c|}{ Sampling Points } \\
\hline & S1 & $\mathbf{S 2}$ & S3 & S4 & S5 & S6 & S7 & S8 \\
\hline SI & $\begin{array}{c}1.71 \pm 0.9 \\
3^{\mathrm{a}}\end{array}$ & $\begin{array}{c}1.66 \pm 1.3 \\
6^{\mathrm{a}}\end{array}$ & $\begin{array}{c}1.77 \pm 1 . \\
06^{\mathrm{a}}\end{array}$ & $\begin{array}{c}2.04 \pm 1.5 \\
7^{\mathrm{a}}\end{array}$ & $\begin{array}{c}1.73 \pm 1.7 \\
4^{\mathrm{a}}\end{array}$ & $\begin{array}{c}1.51 \pm 1.3 \\
7^{\mathrm{a}}\end{array}$ & $\begin{array}{c}1.52 \pm 1.2 \\
6^{\mathrm{a}}\end{array}$ & $\begin{array}{c}0.817 \pm 0 . \\
47^{\mathrm{a}}\end{array}$ \\
\hline $\begin{array}{c}\text { MO } \\
\text { M(g/g } \\
\text { ) }\end{array}$ & $\begin{array}{c}0.17 \pm 0.4 \\
1^{\mathrm{a}}\end{array}$ & $0 \pm 0^{\mathrm{a}}$ & $\begin{array}{c}0.007 \pm \\
0.02^{\mathrm{a}}\end{array}$ & $\begin{array}{c}0.01 \pm 0.0 \\
24^{\mathrm{a}}\end{array}$ & $\begin{array}{c}0.13 \pm 0.3 \\
3^{\mathrm{a}}\end{array}$ & $\begin{array}{c}0.11 \pm 0.2 \\
6^{\mathrm{a}}\end{array}$ & $\begin{array}{c}0.07 \pm 0.1 \\
71^{\mathrm{a}}\end{array}$ & $\begin{array}{c}0.07 \pm 0.1 \\
8^{a}\end{array}$ \\
\hline $\mathbf{B}(\mathbf{m})$ & $\begin{array}{c}7.42 \pm 0.8 \\
0^{c}\end{array}$ & $\begin{array}{c}4.83 \pm 1.0 \\
3^{\mathrm{ab}}\end{array}$ & $\begin{array}{c}5.77 \pm 1 . \\
00^{\mathrm{b}}\end{array}$ & $\begin{array}{c}4.47 \pm 1.8 \\
3^{\mathrm{ab}}\end{array}$ & $\begin{array}{c}4.6 \pm 0.47 \\
\text { ab }\end{array}$ & $\begin{array}{c}3.53 \pm 1.3 \\
9^{\mathrm{a}}\end{array}$ & $\begin{array}{c}5.53 \pm 1.7 \\
7^{b}\end{array}$ & $\begin{array}{c}6.12 \pm 1.4 \\
8^{\mathrm{bc}}\end{array}$ \\
\hline $\mathbf{H}(\mathrm{m})$ & $\begin{array}{c}0.27 \pm 0.0 \\
8^{\mathrm{a}}\end{array}$ & $\begin{array}{c}0.36 \pm 0.1 \\
5^{\mathrm{a}}\end{array}$ & $\begin{array}{c}0.44 \pm 0 . \\
19^{\mathrm{ab}}\end{array}$ & $\begin{array}{c}0.37 \pm 0.2 \\
3^{\text {ab }}\end{array}$ & $\begin{array}{c}0.51 \pm 0.2 \\
7^{\mathrm{ab}}\end{array}$ & $\begin{array}{c}0.39 \pm 0.1 \\
4^{\mathrm{ab}}\end{array}$ & $\begin{array}{c}0.43 \pm 0.2 \\
7^{\mathrm{ab}}\end{array}$ & $\begin{array}{c}0.64 \pm 0.2 \\
7^{\mathrm{b}}\end{array}$ \\
\hline $\begin{array}{c}\text { SS(kg } \\
\text { /l) }\end{array}$ & $\begin{array}{c}0.001 \pm 0 . \\
003^{\mathrm{a}}\end{array}$ & $\begin{array}{c}0.001 \pm 0 . \\
003^{\mathrm{a}}\end{array}$ & $\begin{array}{l}0.001 \pm \\
0.003^{\mathrm{a}}\end{array}$ & $\begin{array}{c}0.003 \pm 0 . \\
004^{\mathrm{a}}\end{array}$ & $\begin{array}{c}0.002 \pm 0 . \\
003^{\mathrm{a}}\end{array}$ & $\begin{array}{c}0.002 \pm 0 . \\
003^{\mathrm{a}}\end{array}$ & $\begin{array}{c}0.001 \pm 0 . \\
003^{\mathrm{a}}\end{array}$ & $\begin{array}{c}0.003 \pm 0 . \\
005^{\mathrm{a}}\end{array}$ \\
\hline $\mathbf{T}(\mathbf{K})$ & $\begin{array}{c}298.11 \pm 1 \\
.05^{\mathrm{a}}\end{array}$ & $\begin{array}{c}298.93 \pm \\
1.21^{\mathrm{abc}}\end{array}$ & $\begin{array}{l}299.78 \\
\pm 0.68^{\mathrm{bc}}\end{array}$ & $\begin{array}{c}298.64 \pm \\
1.67^{\mathrm{ab}}\end{array}$ & $\begin{array}{c}300.58 \pm \\
1.42^{\mathrm{c}}\end{array}$ & $\begin{array}{c}300.31 \pm \\
1.72^{\mathrm{bc}}\end{array}$ & $\begin{array}{c}299.96 \pm 1 \\
.22 b^{c}\end{array}$ & $\begin{array}{c}299.51 \pm \\
0.88^{\mathrm{abc}}\end{array}$ \\
\hline$\underset{(\mathbf{m} / \mathbf{d})}{\mathbf{V}}$ & $\begin{array}{l}31680 \pm 1 \\
7199.2^{\mathrm{ab}}\end{array}$ & $\begin{array}{c}37584 \pm 5 \\
430.2^{\text {ab }}\end{array}$ & $\begin{array}{l}21744 \pm \\
12959^{\mathrm{a}}\end{array}$ & $\begin{array}{c}23616 \pm 1 \\
1690.1^{\mathrm{a}}\end{array}$ & $\begin{array}{c}21600 \pm 1 \\
0694.1^{\mathrm{a}}\end{array}$ & $\begin{array}{l}54000 \pm 3 \\
2858.1^{\mathrm{b}}\end{array}$ & $\begin{array}{l}39888 \pm 2 \\
5375.2^{\text {ab }}\end{array}$ & $\begin{array}{r}24336 \pm 1 \\
6460.6^{a}\end{array}$ \\
\hline
\end{tabular}

Var.=variables; On the same line, values bearing the same letter are not significantly different $(\mathrm{p} \geq 0.05)$; Mom $=$ mass fraction of organic matter in suspended solids; $S S=$ amount of suspended solids; Temp $=$ Temperature; $\mathrm{B}=$ bottom width

The ANOVA revealed that, for the slope, the mass fraction of organic matter in suspended solids (MOM), the depth, the suspended solids (SS) and the velocity, there was no significant difference in the means of hydrological parameters in the various sampling points $(\mathrm{p} \geq 0.05)$. The bottom width (B) had some significant differences in means between points $\mathrm{S} 1$ as compared to $\mathrm{S} 2$, S4, S5 and S6. The mean water temperature also varied significantly between S6 and all the other sampling points throughout the study. Seasonal variation of water hydrology was assessed and presented in table 3 . 
Table 3: Variation of hydrological variables across seasons

\begin{tabular}{|c|c|c|c|c|}
\hline Season & Dry & Rainy & P-value & Statistic \\
\hline SI & $2.11 \pm 1.33$ & $1.08 \pm 0.86$ & 0.003 & 10.19 \\
\hline $\mathbf{M O M}(\mathbf{g} / \mathbf{g})$ & $0.14 \pm 0.29$ & $0 \pm 0$ & 0.02 & 5.66 \\
\hline $\mathbf{B}(\mathbf{m})$ & $5.11 \pm 1.74$ & $5.46 \pm 1.56$ & $\mathbf{0 . 4 7}$ & 0.54 \\
\hline $\mathbf{H}(\mathbf{m})$ & $0.35 \pm 0.17$ & $0.51 \pm 0.24$ & 0.01 & 6.92 \\
\hline $\mathbf{S S}(\mathbf{k g} / \mathbf{l})$ & $0.0036 \pm 0.004$ & $0.00008 \pm 0.00009$ & 0.0003 & 18.56 \\
\hline $\mathbf{T}(\mathbf{K})$ & $299.93 \pm 1.83$ & $299.03 \pm 0.64$ & 0.03 & 5.18 \\
\hline $\mathbf{V}(\mathbf{m} / \mathbf{d})$ & $23436 \pm 13607.03$ & $40176 \pm 22448.10$ & 0.003 & 9.76 \\
\hline
\end{tabular}

The t-test revealed that, apart for the bottom width, there was a significant seasonal variation in all the other parameters. The slope was significantly smaller in the rainy season, idem the mass fraction of organic matter, the suspended solids and the temperature. The velocity and the depth significantly $(\mathrm{p}<0.05)$ decreased in the dry season. The linear uncorrelated variables following PCA are shown in figure 1(spatial) and figure 2(temporal).

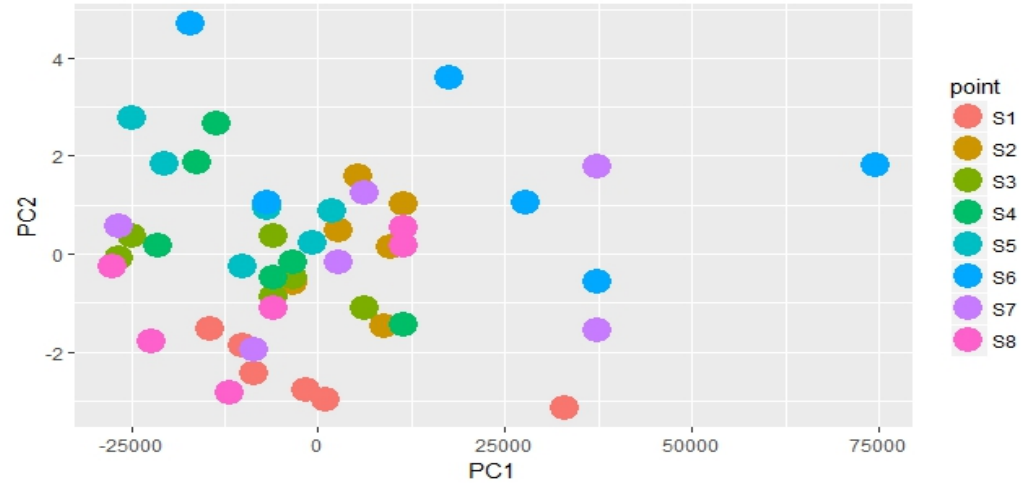

Figure 1: PCA showing linear uncorrelated environmental variables of the Benoe stream across sampling sites

From figure 1, variables of point 6 are a little bit isolated from those in other sampling points. Figure 2 presents linear uncorrelated variables across seasons.

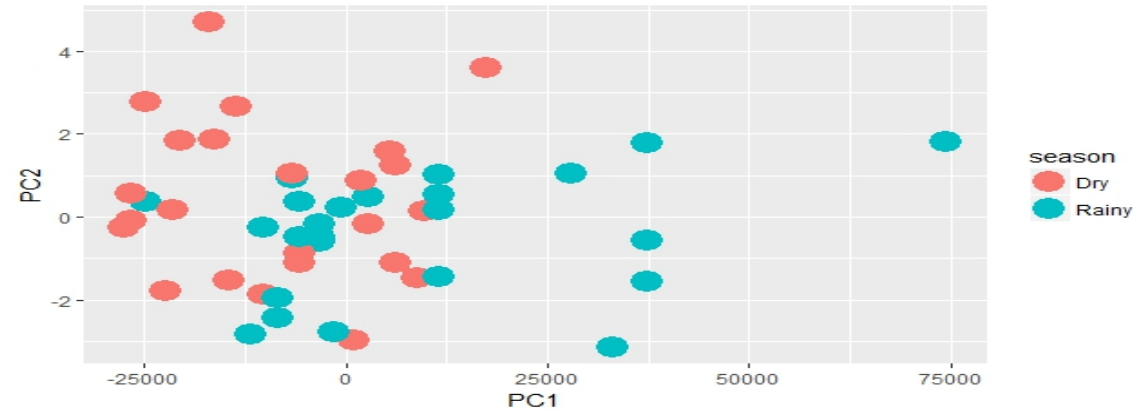

Figure 2: PCA showing linear uncorrelated environmental variables of the Benoe stream across seasons 
It appeared from figure 2 that there was a noticeable seasonal variation on water hydrology. This confirms the necessity to take seasons into account before carrying out risk assessment.

\section{Pesticide risk assessment}

PRIMET predicted 28 (63.6\% of total active ingredients assessed) pesticides to pose no risk (ETR $<1), 7(15.9 \%)$ pesticides to pose a possible risk $(1 \leq$ ETR $\leq 100)$ and $9(20.5 \%)$ pesticides to pose a definite risk (ETR > 100 ) to water (figure 3). Only cypermethrin was predicted to pose a possible chronic risk to water $\left(\mathrm{ETR}_{2}=1, \mathrm{PEC}=0.42 \mu \mathrm{g} / \mathrm{l}\right)$ and fish $\left(\mathrm{ETR}_{2}=5.6\right.$, $\mathrm{PEC}=0.42 \mu \mathrm{g} / \mathrm{l})$. This was the only compound with risks at all the levels (acute, chronic, possible and definite). Seven (15.9\%) pesticides were predicted to pose a possible chronic risk to Daphnia which was more vulnerable to pesticides than fish.

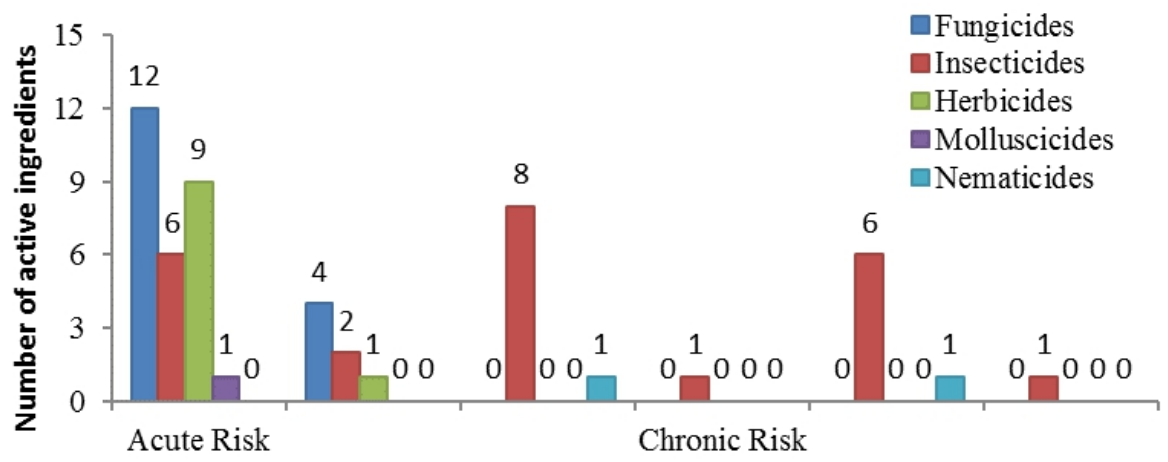

Figure 3: Number of pesticides per families based for each risk category

The pesticide application scheme, PEC and ETR are found in tables 4 (fungicides), 5 (insecticides) and 6 (herbicides-molluscicides-nematicides).

Table 4: Fungicides application rates as determined from surveys, PEC and ETR values

\begin{tabular}{|l|l|c|c|c|c|c|c|c|c|}
\hline \multicolumn{1}{|c|}{$\begin{array}{c}\text { Active } \\
\text { ingredients }\end{array}$} & Crop & $\begin{array}{c}\text { Application } \\
\text { interval } \\
\text { (days) }\end{array}$ & $\begin{array}{c}\text { Applied or } \\
\text { recommended } \\
\text { dose (g.a.//ha) }\end{array}$ & $\begin{array}{c}\text { Number of } \\
\text { applications }\end{array}$ & $\begin{array}{c}\text { PEC } \\
\text { water } \\
(\boldsymbol{\mu g} / \mathbf{l})\end{array}$ & $\begin{array}{c}\text { ETR } \\
\text { water } \\
\text { acute }\end{array}$ & $\begin{array}{c}\text { ETR } \\
\text { water } \\
\text { chronic }\end{array}$ & $\begin{array}{c}\text { ETR } \\
\text { water } \\
\text { chronic } \\
\text { Daphnia }\end{array}$ & $\begin{array}{c}\text { ETR } \\
\text { water } \\
\text { chronic } \\
\text { Fish }\end{array}$ \\
\hline Azoxystrobin & banana & 180 & 100 & 2 & 0.69 & 0.3 & 0.0005 & 0.0007 & 0.0005 \\
\hline Bitertanol & banana & 180 & 300 & 2 & 0.02 & 0.0011 & $2.00 \mathrm{E}-05$ & $2.30 \mathrm{E}-05$ & $2.00 \mathrm{E}-05$ \\
\hline Carbendazim & rubber & 36 & 40 & 10 & 0.28 & 0.11 & $1.20 \mathrm{E}-05$ & $1.20 \mathrm{E}-05$ & 0.0014 \\
\hline Chlorothalonil & banana & 180 & 1000 & 2 & 0.5 & 4.5 & 0.0019 & 0.0019 & 0.0041 \\
\hline $\begin{array}{l}\text { Copper } \\
\text { hydroxide }\end{array}$ & cocoa & 3 & 50 & 40 & 0.19 & 0.24 & 0.0066 & 0.0066 & $/$ \\
\hline Difenoconazole & banana & 180 & 100 & 2 & 0.55 & 0.071 & 0.0068 & 0.013 & 0.0068 \\
\hline Epoxiconazole & banana & 180 & 100 & 2 & 0.64 & 3.83 & 0.0002 & 0.0002 & 0.0072 \\
\hline Fenpropimorph & banana & 180 & 616 & 2 & 4.4 & 0.11 & 0.0002 & 0.0002 & 0.08 \\
\hline Imazalil & banana & 180 & 1 & 2 & 0.0053 & 0.0002 & $1.90 \mathrm{E}-07$ & $1.90 \mathrm{E}-07$ & $1.20 \mathrm{E}-05$ \\
\hline
\end{tabular}




\begin{tabular}{|l|l|c|c|c|c|c|c|c|c|}
\hline Mancozeb & banana & 180 & 2000 & 2 & 13 & 18 & 0.16 & 0.16 & 0.4 \\
\hline Maneb & tomato & 2 & 100 & 31 & 0.69 & 0.49 & 0.003 & 0.003 & 0.17 \\
\hline Metalaxyl & cocoa & 20 & 50 & 15 & 0.35 & 0.0014 & $4.10 \mathrm{E}-06$ & $4.10 \mathrm{E}-06$ & $8.60 \mathrm{E}-06$ \\
\hline Propiconazole & banana & 180 & 100 & 2 & 0.66 & 0.07 & $9.20 \mathrm{E}-06$ & $9.20 \mathrm{E}-06$ & 0.001 \\
\hline Pyraclostrobin & rubber & 180 & 100 & 2 & 0.42 & 7 & 0.008 & 0.01 & 0.008 \\
\hline Tebuconazole & coffee & 30 & 59 & 4 & 0.39 & 0.0093 & 0.0004 & 0.0004 & 0.0036 \\
\hline Thiabendazole & banana & 180 & 500 & 2 & 2.2 & 0.4 & 0.007 & 0.007 & 0.02 \\
\hline
\end{tabular}

Table 5: Insecticides application rates as determined from surveys, PEC and ETR values

\begin{tabular}{|c|c|c|c|c|c|c|c|c|c|}
\hline $\begin{array}{c}\text { Active } \\
\text { ingredients }\end{array}$ & Crop & $\begin{array}{c}\text { Application } \\
\text { interval } \\
\text { (days) }\end{array}$ & $\begin{array}{c}\text { Applied or } \\
\text { recommended } \\
\text { dose (g.a.i/ha) }\end{array}$ & $\begin{array}{l}\text { Number of } \\
\text { applications }\end{array}$ & $\begin{array}{l}\text { PEC }_{1} \\
\text { water } \\
(\mu \mathrm{g} / \mathrm{l})\end{array}$ & $\begin{array}{c}\text { ETR } \\
\text { water } \\
\text { acute }\end{array}$ & $\begin{array}{c}\text { ETR } \\
\text { water } \\
\text { chronic }\end{array}$ & $\begin{array}{c}\text { ETR } \\
\text { water } \\
\text { chronic } \\
\text { Daphnia }\end{array}$ & $\begin{array}{c}\text { ETR } \\
\text { water } \\
\text { chronic } \\
\text { Fish }\end{array}$ \\
\hline Acetamiprid & cocoa & 30 & 1000 & 4 & 7.1 & 0.014 & $3.90 \mathrm{E}-05$ & 0.0002 & $\begin{array}{l}3.90 \mathrm{E}- \\
05\end{array}$ \\
\hline Bifenthrin & tomato & 21 & 147 & 2 & 0.06 & 10 & 0.03 & 3.3 & 0.03 \\
\hline Cadusafos & banana & 180 & 5600 & 2 & 39 & $5.20 \mathrm{E}+03$ & 0.83 & 25 & 0.83 \\
\hline Carbofuran & banana & 180 & 5600 & 2 & 40 & 201 & 0.17 & 0.71 & 0.17 \\
\hline Chlorpyrifos & corn & 30 & 73.5 & 2 & 0.26 & 263 & 0.062 & 0.062 & 0.17 \\
\hline Cypermethrin & tomato & 7 & 441 & 7 & 0.42 & 714 & 1 & 1 & 5.6 \\
\hline Deltamethrin & corn & 60 & 73.5 & 6 & 0.51 & 255 & 0.06 & 0.06 & 0.11 \\
\hline Dimethoate & tomato & 15 & 14.7 & 8 & 0.088 & 0.0019 & 0.0002 & 0.0008 & 0.0002 \\
\hline Fipronil & cocoa & 60 & 88 & 6 & 0.6 & 0.32 & 0.0013 & 0.0013 & 0.0045 \\
\hline Imidacloprid & cocoa & 56 & 4412 & 3 & 29 & 0.033 & 0.0003 & 0.0024 & 0.0003 \\
\hline $\begin{array}{l}\text { Lambda- } \\
\text { cyhalothrin }\end{array}$ & cocoa & 30 & 1000 & 4 & 0.55 & $3.40 \mathrm{E}+03$ & 0.12 & 6.7 & 0.12 \\
\hline Lindane & cocoa & 180 & 735.3 & 2 & 4.8 & 166 & $1.30 \mathrm{E}-05$ & $1.30 \mathrm{E}-05$ & 0.0002 \\
\hline Malathion & beans & 184 & 441 & 2 & 2.8 & 398 & 0.0018 & 3.7 & 0.0018 \\
\hline Novaluron & tomato & 21 & 147 & 2 & 1 & 0.18 & 0.03 & 3.8 & 0.03 \\
\hline Oxamyl & banana & 180 & 2044 & 2 & 15 & 4.6 & 0.0014 & 0.05 & 0.0014 \\
\hline Thiamethoxam & cocoa & 7 & 2500 & 9 & 18 & 0.02 & $7.90 \mathrm{E}-05$ & 7.90E-05 & 0.0004 \\
\hline
\end{tabular}

Table 6: Herbicides, molluscicides and nematicides application rates as determined from surveys, PEC and ETR values

\begin{tabular}{|c|c|c|c|c|c|c|c|c|c|}
\hline $\begin{array}{c}\text { Active } \\
\text { ingredients }\end{array}$ & Crop & $\begin{array}{l}\text { Application } \\
\text { interval } \\
\text { (days) }\end{array}$ & $\begin{array}{c}\text { Applied or } \\
\text { recommended } \\
\text { dose (g.a.i/ha) }\end{array}$ & $\begin{array}{l}\text { Number of } \\
\text { applications }\end{array}$ & $\begin{array}{l}\mathrm{PEC}_{1} \\
\text { water } \\
(\mu \mathrm{g} / \mathrm{l})\end{array}$ & $\begin{array}{c}\text { ETR } \\
\text { water } \\
\text { acute }\end{array}$ & $\begin{array}{c}\text { ETR } \\
\text { water } \\
\text { chronic }\end{array}$ & $\begin{array}{c}\text { ETR } \\
\text { water } \\
\text { chronic } \\
\text { Daphnia }\end{array}$ & $\begin{array}{c}\text { ETR } \\
\text { water } \\
\text { chronic } \\
\text { Fish }\end{array}$ \\
\hline Clethodim & corn & 120 & 147 & 1 & 1.1 & 0.0016 & $2.50 \mathrm{E}-06$ & $2.50 \mathrm{E}-06$ & $2.90 \mathrm{E}-05$ \\
\hline Diuron & weeds & 365 & 295 & 1 & 2.1 & 0.94 & 0.006 & 0.003 & 0.0006 \\
\hline Glyphosate & coffee & 180 & 588 & 2 & 4.2 & 0.07 & $1.70 \mathrm{E}-05$ & $2.70 \mathrm{E}-05$ & $1.70 \mathrm{E}-05$ \\
\hline Glyphotrimesium & banana & 365 & 588 & 1 & 4.2 & 0.035 & $9.30 \mathrm{E}-06$ & 0.0006 & $9.30 \mathrm{E}-06$ \\
\hline Nicosulfuron & corn & 30 & 147 & 3 & 1 & 0.0016 & $1.20 \mathrm{E}-05$ & $3.00 \mathrm{E}-05$ & $1.20 \mathrm{E}-05$ \\
\hline Oxadiazon & weeds & 365 & 29.5 & 1 & 0.18 & 0.3 & 0.0005 & 0.0005 & 0.022 \\
\hline Paraquat & weeds & 90 & 442 & 3 & 0.041 & 1.8 & $5.20 \mathrm{E}-05$ & $5.20 \mathrm{E}-05$ & \\
\hline
\end{tabular}




\begin{tabular}{|l|c|c|c|c|c|c|c|c|c|}
\hline Metaldehyde & banana & 365 & 12000 & 1 & 86 & 0.11 & 0.0001 & 0.0001 & 0.0002 \\
\hline Ethoprophos & banana & 120 & 54000 & 3 & 386 & 406 & 0.66 & 10 & 0.66 \\
\hline
\end{tabular}

From the above tables (4, 5 and 6), it seems that herbicides, molluscicides and fungicides were generally less risky compounds than insecticides and nematicides.

\section{Discussion}

\section{Seasonal variation in water parameters}

Due to seasonal variation and the contribution of tributaries and points sources, water hydrology may be subjected to some changes. Variations may also be related to anthropologic pressure on the stream. According to Zhang et al. (2012), environmental degradation and rapid socioeconomic growth drastically changed the patterns of flow discharge in China's river basins. In the dry season, almost half of the stream is diverted into the CDC farm for irrigation, pesticide application and banana processing purposes. This may account for the seasonal variation in the water parameters of the stream. Hydro-meteorological factors such as water flow, rainfall and temperature change significantly relate to the temporal and spatial dynamics of phytoplankton (Li et al., 2013).

\section{Risk Assessment \\ The "no risk" category}

Most of the active ingredients $(63.6 \%)$ were predicted to pose minor risk. The toxicity of pollutants to aquatic organisms is influenced by water physico-chemistry, concentration of the chemical and the physiological state of the organism (Mischke and Avery, 2013). Pesticide ability to persist may also determine its potential to pose risk. The persistence, measured as halflife is determined by degradation processes such as biodegradation, metabolisms, hydrolysis, photolysis and oxidation (FAO, 2010b). If degradation is rapid, then the compound may be unlikely to pose a serious risk especially a chronic one. The faster a given pesticide breaks down in the environment, the less threat it poses to aquatic life (Sarwar, 2012). In addition, on the population level, effects of pesticides depend not only on exposure and toxicity, but also on factors such as life history characteristics, population structure, timing of application, presence of refuges in time and space, and landscape structure (Schmolke et al. 2010).

\section{Herbicides}

Ten herbicides were assessed and nine were predicted to pose no risk. It has been reported that, many herbicides are found in surface and groundwater worldwide in varying concentration (Leblanc, 2004), but they 
are usually more toxic to plants since animals lack their target enzyme. Herbicides are generally less toxic to aquatic organisms than insecticides (Helfrich, 2009).

The ability of diuron to pose no risk may be related to the long application interval at relatively low dosage. Also, this pesticide has been reported to show moderate toxicity to aquatic invertebrates (Giacomazzi and Cochet, 2004) and it is less hazardous to fish (Mhadhbi and Beiras, 2012) despite its detection in water above its lowest benchmark (Ensminger et al., 2013).

Oxadiazon, a pre-emergence selective herbicide that inhibits protoporphyrinogen oxidase was predicted to pose no risk probably because of its low application rate and moderate toxicity to fish and Daphnia (IUPAC, 2017). In addition to this oxadiazon was reported by Fourie (1992) to exhibit less persistence as compared to other pre-emergence herbicides.

Glufosinate ammonium is a herbicide which is highly soluble in water. Applied on banana, its low application rate may justify its classification in the no risk category even though the dosage was relatively high. This pesticide shows a moderate to low toxicity to most aquatic organisms (IUPAC, 2017). Its persistence is also relatively low (Syan et al., 2014) making it less risky.

Glyphosate is a non-selective herbicide, the world's most widely used herbicide (Evan et al., 2007). Kenko et al. (2017) also reported that glyphosate was the most used herbicide in the Fako Division, South West Cameroon. It is moderately toxic to most aquatic organisms (IUPAC, 2017) and low application rate and dosage might have accounted for its capacity to pose no risk. In a previous study, this pesticide had an ETR=0.2 putting it in the no risk category (Malherbe et al., 2013). This value is larger than the 0.07 ETR value found in this study but both values are lower than 1 . In water glyphosate bound to suspended particles and bottom sediments and is rapidly inactivated (Helfrich, 2009).

Glyphosate trimesium is a non-selective herbicide used in banana farms at CDC once a year, it has a high degradability; this low persistence and long application interval may explain its ability to pose no risk. Also, IUPAC (2017) reported it to be moderately toxic to most aquatic organisms. This compound has even been recommended for combination with biocontrol in IPM, a sustainable and eco-friendly technique because of its low toxicity to aquatic vertebrates (Mohan, 2011).

Triclopyr is a herbicide for perennial broad-leaved and woody weed control. Despite its detection in water and sediments around urban areas in California (Ensminger et al., 2013), it was predicted to pose no risk. This may be related to its low application frequency and moderate persistence 
(DT50-water=24.8days). So its presence in water or sediments samples may be punctual.

Nicosulfuron is a post-emergence selective herbicide. This compound was reported to have a relatively higher persistence in water (DT-50 $=75 \mathrm{~d})$ as compared to other sulfonylurea herbicides (Cessna et al., 2015. Nevertheless, it was predicted to pose no risk probably because of its use in relatively low dosage.

2,4-D is a selective systemic herbicide highly soluble in water and slightly toxic to fish and aquatic invertebrates (IUPAC, 2017). It was used at moderate dosage (221ga.i/ha), hence its capacity to pose no risk. This compound has been detected in water and sediment samples (Ensminger et al., 2013) but it rapidly and completely decomposes in about 3 weeks (Helfrich, 2009).

Clethodim is a systemic herbicide used to control annual and perennial grasses. It was predicted to pose no risk probably because of the low application rate and high degradability. In addition, new families of herbicides have low toxicity to animals (Leblanc, 2004).

\section{Fungicides}

Of the 16 fungicides assessed, 12 were predicted to pose no risk. This goes along with the findings of Leblanc (2004) for whom fungicides may be relatively non-toxic even though their hydrolysis yields carcinogens such as ethylthiourea. Helfrich (2009) also found that fungicides are not as highly toxic to fish and aquatic animals as insecticides.

Thiabendazole is post-harvest fungicide with systemic action; it compromises the cytoskeleton (IUPAC, 2017). It is used on banana by the CDC at 500g.a.i/ha twice a year; this application interval may explain its ability to pose no risk. Idem like Maneb, a fungicide that has a multi-site activity and a non-specific mode of action. It did not pose risk because of

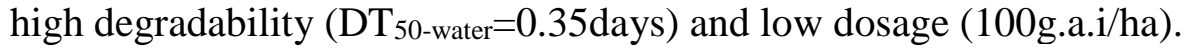

Copper hydroxide is a fungicide used on cocoa. With a very long DT $_{50 \text {-water }}(1.0 \mathrm{E}+6$ days), it was used for cocoa at $50 \mathrm{~g} . \mathrm{a} . \mathrm{i} / \mathrm{ha}$, this low dosage may justify its ability to pose no risk. Also, its long DT50-water is due to its heavy metal component $(\mathrm{Cu})$. Copper is among the most hazardous heavy metals for health (Chevalier et al., 2003) and it accumulates in fish liver and kidneys but its concentration is expected to be metabolically regulated in vertebrates since it is an essential element (Metcheva et al., 2010). Rauf and Javed (2007) showed a significant relationship between accumulation of plankton and water physico-chemistry but PRIMET predicted it to pose no risk; in fact environmental conditions (oxygen, temperature, hardness, salinity, other metals) may also affect metal toxicity. 
Azoxystrobin is a post-emergence broad-spectrum fungicide that was used on banana by the CDC. It is moderately toxic to most aquatic life (IUPAC, 2017) hence its potential to pose no risk. It was also applied at relatively low dosage. Azoxystrobin residues have been detected in water bodies (Telo et al., 2015) but its degradation is faster in alkaline $\mathrm{pH}$ (Singh et al. 2010).

Fenpropimorph is a fungicide having a systemic action. It was used on banana at 616g.a.i/ha twice a year and because of its high degradation rate (DT 50 -water is 2.65 days), it could not pose a risk.

Carbendazim is a fungicide with a low aqueous solubility. It can be very persistent in water systems (Grogan and Jukes, 2003), but it was used at low dosage (40g.a.i/ha). Its moderately toxicity to most aquatic organisms may explain why PRIMET predicted it to pose no risk. This result corroborates those of Malherbe et al. (2013) who also predicted this active ingredient to pose no risk to water $(\mathrm{ETR}=0.2)$; the ETR value $(0.11)$ of this study is even smaller.

Difenoconazole is a broad-spectrum fungicide. It was used on banana twice a year at 100g.a.i/ha. Having it in the no risk group goes along with its moderate toxicity to most aquatic organisms (IUPAC, 2017), low dosage and low application rate. It may be detected in water bodies (Telo et al., 2015) but the quantity and the persistence may be at acceptable levels.

Propiconazole is systemic fungicide acting via the demethylation of C-14 during ergosterol biosynthesis (IUPAC, 2017). It was predicted to pose no risk because of its high degradability ( $\mathrm{DT}_{50 \text {-water }}=6$ days), low application rate and dosage on CDC banana (twice a year at 100g.a.i/ha).

Bitertanol is a fungicide with moderate toxicity and low solubility

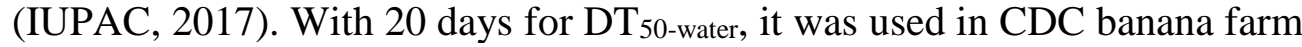
at 300g.a.i/ha twice a year. This application scheme justifies its classification in the no risk category.

Tebuconazole is a systemic fungicide that inhibits sterol biosynthesis disrupting membrane function (IUPAC, 2017). The low application dose (59g.a.i /ha) may explain its prediction to pose no risk. This result corroborates the findings of Malherbe et al. (2013) who had an ETR=0.04; the value of this study is smaller $(\mathrm{ETR}=0.0093)$.

Metalaxyl is a systemic fungicide. It was used for cocoa in this study at 50g.a.i/ha. This low dosage may justify its ability to pose no risk together with its moderate degradability.

Imazalil is a systemic fungicide which disrupts membrane function (IUPAC, 2017). This is the less risky compound of this survey. It was used for banana cultivation at CDC with 2 applications per year; this may justify its low ETR. 


\section{Insecticides}

Fripronil is a broad-spectrum insecticide. It may occurs in relatively high dose in water samples (Ensminger et al., 2013) but its use on cocoa at low dosage may account for its ability to pose no risk. Idem like novaluron, a growth regulator (chitin synthesis inhibitor) used to control a range of pests. It was predicted to pose no risk because of its low persistence (DT50water $=0.95$ days) and its relatively low dosage and application rate.

Imidacloprid is a neonicotinoid insecticide, highly soluble and nontoxic to fish (IUPAC, 2017); this may be why it was predicted to pose no risk even though according to laboratory work, this pesticide caused an increase in the mortality of fish with the duration of exposure (Bhavika and Pragna, 2014). Its classification in the no risk group here may assume that the toxicity depends on other environmental variables.

Thiamethoxam is an insecticide that shows a broad spectrum systemic action. It was used on cocoa at 2500g.a.i/ha. Despite this high dosage, its ability to pose no risk is due to its low toxicity (IUPAC, 2017) and low persistence even though thiamethoxan residues have been detected in irrigation water in rice farms (Telo et al., 2015). The amount detected might be either negligible or its presence might be punctual in water.

Acetamiprid is an insecticide highly soluble in water that may be very persistent in aquatic systems. It was predicted to pose no risk because of its moderate toxicity to most aquatic organisms and relatively low application rate.

Dimethoate is an organophosphate insecticide highly soluble in water. Illegally used in Cameroon (Kenko et al., 2017), it does not normally persist in aerobic aquatic systems and its moderate toxicity to most aquatic species (IUPAC, 2017) accounted for its ability to pose no risk. In this study it was used on tomato at relatively low dosage. These results corroborate the findings of Malherbe et al. (2013) who predicted dimethoate to pose no risk $(\mathrm{ETR}=0.01)$.

\section{Molluscicides}

Metaldehyde is a contact and systemic molluscicide used to control slugs and snails. Hundreds of snails are caught daily by villagers to prepare a meal locally known as "congo meat"; this may contribute to a reduction of molluscicide-dependence, hence its one year application frequency and its inability to pose aquatic risk even in high dosage (12000g.a.i/ha). In addition, it has a low persistence based on its half-life in water.

\section{The "possible risk" category}

Seven active ingredients $(15.9 \%)$ were predicted to pose a possible risk. The environmental fate of a pesticide depends on factors such as the soil 
sorption coefficient, the solubility, the saturated vapour pressure and molar mass. These parameters can be used to predict the environmental fate of a pesticide (FAO, 2010b). Aquatic organisms in streams flowing through croplands are likely to receive repeated low doses of pesticides from runoff (Helfrich, 2009).

Mancozeb is a broad-spectrum fungicide having low aqueous solubility but it may be persistent in water. Its ability to pose a possible risk may be related to its high toxicity to fish and aquatic invertebrates (IUPAC, 2017). Also, it was applied in a relatively high dosage (2000g.a.i/ha).

Bifenthrin is a parathyroid insecticide having low aqueous solubility. Used twice a season on tomato $147 \mathrm{~g}$.a.i/ha, this sodium channel modulator has been reported to be toxic to most aquatic organisms (IUPAC, 2017), hence its ability to pose a possible risk. Bifenthrin was reported by Ensminger et al. (2013) to be a serious contaminant in water samples in a study carried out in California; it was found above the lowest USEPA aquatic benchmark.

Pyraclostrobin is a fungicide that inhibits respiration. This compound is highly toxic to fish and aquatic invertebrates $\left(\mathrm{LC}_{50-\text { fish }}=0.006 \mathrm{mg} / 1, \mathrm{LC}_{50}\right.$ Daphnia $=0.016 \mathrm{mg} / \mathrm{l})$ hence the prediction to pose a possible risk despite the low application rate.

Oxamyl is a soil-applied insecticide. With a systemic action, it acts as acetyl cholinesterase inhibitor (IUPAC, 2017). The application dose was 2044g.a.i/ha on banana 2 times a year. Its ETR value may be related to this use in relatively high dose.

Chlorothalonil has a low aqueous solubility and it may be persistent in water. With a great bioaccumulation potential, Chlorothalonil is toxic to aquatic organisms (IUPAC, 2017) and the application rate was 1000g.a.i/ha on banana two times a year, making it risky for the aquatic milieu.

Epoxiconazole is a broad-spectrum fungicide that may persist in water systems. It was used in relative low dose and it has a low bioaccumulation capacity (IUPAC, 2017). So its presence in the possible risk category may be related to its DT50-water (65.8days) and its moderate toxicity to most aquatic organisms.

Paraquat is an herbicide with a broad-spectrum action. It has high degradability, stable in sediments and was used in moderate rate (442g.a.i/ha, three times a season). This application rate may justify its ability to pose a possible risk. In the same line, Malherbe et al. (2013) reported Paraquat $(\mathrm{ETR}=73)$ to pose a possible risk to water in South Africa. In the study, a lower $\mathrm{ETR}=1.8$ was obtained but both values are in the possible risk category. 


\section{The "definite" risk category}

Nine pesticides (20.5\%), including 8 insecticides were predicted by PRIMET to pose a definite risk. Insecticides are extremely hazardous to fish and wildlife and their capacity to harm fish and aquatic animals is largely a function of their toxicity, exposure time, dose rate and persistence in the environment (Helfrich, 2009). Insecticide contamination is a major risk for biodiversity in water bodies (Sarwar, 2012). The impact of pesticides on water is tributary to many pesticide related factors such as active ingredient formulation, impurities, additives, depredates (FAO, 2010). Factors accounting for frequent water pollution by pesticides include spray drift, runoff, leaching or direct application of pesticides onto surface water (PAN, 2010).

Cadusafos is an organophosphate insecticide having a moderate aquatic solubility and can be persistent in water systems (IUPAC, 2017). The $\mathrm{LC}_{50 \text {-Daphnia }}=0.75 \mu \mathrm{g} / \mathrm{l}<\mathrm{PEC}=39 \mu \mathrm{g} / \mathrm{l}$, therefore, it can be toxic even at low dosage. It is highly toxic to most aquatic organisms and since it was used in high rate (5600g.a.i/ha of banana two times a year), it is not surprising to have it as the most risky compound in this study with the highest ETR (5200).

Lambda-cyhalothrin is a pyrethroid insecticide with a low aqueous solubility. Acting as sodium channel modulator, it is highly toxic to fish and aquatic invertebrates. It definitely posed a risk because of the high rate of application (4 times a season) in addition to its high toxicity to Daphnia $\left(\mathrm{LC}_{50}=0.36 \mu \mathrm{g} / 1<\mathrm{PEC}=0.55 \mu \mathrm{g} / \mathrm{l}\right)$.

Cypermethrin is a pyrethroid insecticide with a low aqueous solubility. Its high toxicity to Daphnia $\left(\mathrm{LC}_{50}=0.36 \mu \mathrm{g} / \mathrm{l}<\mathrm{PEC}=0.42 \mu \mathrm{g} / \mathrm{l}\right)$ and the number of applications (441g.a.i/ha 7 times per season) account for its ability to pose a risk. IUPAC (2017) reported it to be a serious marine pollutant. PRIMET predicted this insecticide to pose a possible risk to water (ETR=55) in a study led by Ansara-Ross et al. (2008) in South Africa. The ETR value for this study is quite higher $(\mathrm{ETR}=714)$.

Ethoprophos is abroad-spectrum nematicides. This chemical is highly

toxic to fish $\left(\mathrm{LC}_{50}=320 \mu \mathrm{g} / 1<\mathrm{PEC}=386 \mu \mathrm{g} / \mathrm{l}\right)$ and Daphnia $\left(\mathrm{LC}_{50}=200 \mu \mathrm{g} / \mathrm{l}<\mathrm{PEC}=386 \mu \mathrm{g} / \mathrm{l}\right)$. In addition, it was used in high dose (54000g.a.i/ha in CDC banana farms). Its toxicity and application dose are closely linked to its ability to be risky in aquatic systems.

Malathion is an insecticide that is moderately soluble in water. It has been detected above the lowest US EPA aquatic benchmark (Ensminger et al., 2013) but it is not usually persistent in water systems (IUPAC, 2017).However it is highly toxic to aquatic species ( LC $_{50}$ Daphnia $=0.7 \mu \mathrm{g} / 1<\mathrm{PEC}=2.8 \mu \mathrm{g} / \mathrm{l})$ with the exception of algae, hence its ability to 
pose a definite risk. In a previous study, this compound was reported by Kenko et al. (2017) to be used in an unorthodox manner.

Chlorpyrifos is an organophosphate (acetyl cholinesterase inhibitor) that is not usually persistent in water systems (IUPAC, 2017). It is extremely hazardous to fish (Mhadhbi and Beiras, 2012) and aquatic invertebrates $\left(\mathrm{LC}_{50-\text { Daphnia }}=0.10 \mu \mathrm{g} / 1<\mathrm{PEC}=0.26 \mu \mathrm{g} / 1\right)$, this may explain its ability to pose a definite risk even at low dosage (73.5g.a.i/ha).

Deltamethrin $(\mathrm{ETR}=255, \mathrm{PEC}=0.51 \mu \mathrm{g} / \mathrm{l})$ is a fast-acting pyrethroid insecticide with low aqueous solubility. It presents a high risk to most aquatic organisms $\left(\mathrm{LC}_{50}\right.$-Fish $\left.=0.56 \mu \mathrm{g} / 1<\mathrm{PEC}=0.51 \mu \mathrm{g} / \mathrm{l}\right)$ and was used 6 times a season on corn hence the ability to pose a risk even at low dose (73.5g.a.i/ha). This pesticide was classified into two categories by Malherbe et al. (2013) since it posed a possible risk $(\mathrm{ETR}=49.9)$ when used on maize and a definite risk (ETR=208) when used on cotton because of different dosage and application intervals. Ansara-Ross et al. (2008) also grouped it in the possible risk category $(\mathrm{ETR}=75)$ in the Crocodile Marico catchment in South Africa.

Carbofuran is an insecticide with moderate solubility in water. Its presence in the definite risk category may be related to its ability to persist in water, its moderate to high toxicity to most aquatic organisms ( $\mathrm{LC}_{50}$ Daphnia $=9.4 \mu \mathrm{g} / 1<\mathrm{PEC}=40 \mu \mathrm{g} / \mathrm{l})$ and high application dose $(5600 \mathrm{~g} \cdot \mathrm{a} . \mathrm{i} / \mathrm{ha}$ on banana).

Lindane is an insecticide having low aqueous solubility; this illegally used compound in Cameroon (Kenko et al., 2017) is a GABA-gated chloride channel antagonist. It was used on cocoa at 735.3g.a.i/ha two times a season. Its potential to pose a definite risk in water may be related to its high persistence and high toxicity to fish ( $\mathrm{LC}_{50-\mathrm{Fish}}=2.9 \mu \mathrm{g} / 1<\mathrm{PEC}=4.8 \mu \mathrm{g} / \mathrm{l}$ ). Lindane was earlier identified as an obsolete pesticide in Cameroon, present in form of Gammophele 320® and Callindim Fc320® for a total of 35,605 litres (Souop, 2000).

\section{Chronic risk}

Cypermethrin was the only active ingredient able to pose a possible chronic risk to water and fish $\left(\mathrm{ETR}_{2}=1, \mathrm{PEC}=0.42 \mu \mathrm{g} / \mathrm{l}\right)$. From a study led by Olufayo and Alade (2012), this compound is known to bring about pathological changes and alterations in fish. Exposure of fish to pesticides depends on its bioavailability, bioconcentration, biomagnification and persistence in the environment (Helfrich, 2009). Literature says cypermethrin is highly toxic to fish and is a serious aquatic pollutant (IUPAC, 2017). Daphnia was more sensitive to fish to pesticides than fish; in fact, pesticide used is responsible for the absence of zooplankton in water around agricultural areas with the proliferation phytoplankton (Rissik et al., 2009). 


\section{Conclusion}

This study aimed at assessing chemical pollution with pesticide in the Benoe Stream using the PRIMET model. A significant seasonal variation in water parameters was noticed. Out of the 44 active ingredients tested, 28 were predicted to pose minor risk; seven indicated a possible acute risk and nine presented a definite acute risk to the aquatic ecosystem. For chronic risk, two compounds, showed a possible risk to water and fish while seven presented a risk to Daphnia. Cypermethrin is the most hazardous compound since it indicated both acute and chronic risk; also, Daphnia appeared to be more sensitive to pesticides than fish. Cadusafos had the highest ETR value while imazalil was the less risky compound in the study. The PRIMET model is a tremendous tool for developing countries like Cameroon where no record in literature makes mention of pesticide risk assessment. Pesticide use in plantations near water bodies can pose a risk to non-target organisms. These compounds should then be used with care as part of IPM. The impact of pesticides on water quality, their bioaccumulation potential and their impact on aquatic biota community structure is necessary.

\section{Acknowledgements}

The research team is grateful to Dr. Christopher Mbua (CDC Research Office) and field guides Yacouba and Augustine Fontsa of the $\mathrm{CDC}$ irrigation service for their assistance.

\section{References:}

1. Ansara-Ross, T.M., Wepener, V., Van den Brink, P.J. and Ross, M.J. (2008). Probabilistic risk assessment of the environmental impact of pesticides in the Crocodile (west) Marico catchment, North-West Province. Water SA 34(5):637-644.

2. Bhavika, D. and Pragna, P. (2014). Behavioural responses to acute exposure of Imidacloprid and Curzate on Labeo rohita (Hamilton, 1822). International Journal of Open Scientific Research 2 (1): 1-12.

3. Cessna, A.J., Donald, D.B., Bailey, J. and Waiser, M. (2015). Persistence of the Sulfonylurea Herbicides Sulfosulfuron, Rimsulfuron, and Nicosulfuron in Farm Dugouts (Ponds). Journal of Environmental Quality 44 (6):1948-1955.

4. Chevalier, P., Cordier, S., Dab, W., Gerin, M., Gossselin, P., Quenel, P. (2003). Santé Environnementale; in Gérin M., Gosselin P., Cordier S., Viau, C., Quénel, P. and Dewailly, E. (eds). Environnement et santé publique: Fondements et Pratiques. Edisem, Québec, Canada, $1023 \mathrm{p}$. 
5. Daam, M.A. and Van den Brink, P.J. (2010). Implications of differences between temperate and tropical freshwater ecosystems for the ecological risk assessment of pesticides. Ecotoxicology 19:24-37.

6. Ensminger, M.P., Budd, R., Kelley, K.C. and Goh, K.S. (2013). Pesticide occurrence and aquatic benchmark exceedances in urban surface waters and sediments in three urban areas of California, USA, 2008-2011. Environ Monit Assess 185:3697-3710.

7. Evan, H., Matt, B. and Kate, J. (2007). The Fate and Effect of Glyphosate on Amphibians. Final Report ENSC 202. 10p.

8. FAO (Food and Agriculture Organisation) (2010a). La Biodiversité Aquatique des Eaux Intérieures. http://www.fao.org/biodiversity (Accessed on $27^{\text {th }}$ August 2010).

9. FAO (Food and Agriculture Organisation) (2010b). Pesticides as water pollutants. URL: http://www.fao.org/docrep/w2598e/w2598e07.htm (Accessed on 1211-2010).

10. Fourie, J.C. (1992). Herbigation in a Vineyard: persistence of four pre-emergence herbicides in a sandy loam soil. South African Journal of Enology and Viticulture 13(2):64-70.

11. Giacomazzi, S. and Cochet, N. (2004). Environmental impact of diuron transformation: a review. Chemosphere 56(11):1021-1032.

12. Helfrich, L.A. (2009). Pesticides and aquatic animals: a guide to reducing impacts on aquatic systems. URL: https://www.pubs.ext.vt.edu/420/420-013/420-013.html. Accessed: July 2017.

13. IUPAC (International Union of Pure and Applied Chemistry) (2017). IUPAC Footprint Pesticide Properties Database (PPDB). URL:http://sitem.hert.ac.uk/aeru/iupac/ (Accessed May 2017).

14. Kenko, N.D.B., Patricia, B.A.F., Ngameni, T.N. and Mpoame, M. (2017). Environmental and human health assessment in relation to pesticide use by local farmers and the Cameroon Development Corporation (CDC), Fako Division, South-West Cameroon. European Scientific Journal 13(21):454-473.

15. Leblanc, G.A. (2004). Basics of environmental toxicology. In: A Textbook of Modern Toxicology, Third Edition, (eds): Ernest Hodgson, John Wiley \& Sons, ISBN: 0-471-26508-X.

16. Li, F., Zhang, H., Zhu, Y., Xiao, Y., Chen, L. (2013). Effect of flow velocity on phytoplankton biomass and composition in a freshwater lake. Science of the Total Environment 447:64-71.

17. Malherbe, W., Van Vuren, J.H.J. and Wepener, V. (2013). Preliminary risk assessment of common-use pesticides using 
PRIMET and PERPEST pesticide risk models in a semi-arid subtropical region. Water SA 39(5):599-609.

18. Metcheva, R., Yurukova, L., Bezukov, V., Beltvheva, M., Yankov, Y. and Dimitrov, K. (2010). Trace and toxic elements accumulation in food chain representatives at Livingston island (Antarctica). International Journal of Biology 2(1):155-161.

19. Mhadhbi, L. and Beiras, R. (2012). Acute Toxicity of Seven Selected Pesticides (Alachlor, Atrazine, Dieldrin, Diuron, Pirimiphos-Methyl, Chlorpyrifos, Diazinon) to the Marine Fish (Turbot, Psetta maxima), Water Air Soil Pollut 223: 5917-5930.

20. Michaud, J.P. and Wierenga, M. (2005). Estimating discharge and stream flows: a guide for sand and gravel operators. Ecology Publication Number 05-10-070, 37p.

21. Mischke, C. and Avery, J. (2013). Toxicities of agricultural pesticides to selected aquatic organisms. SRAC (Southern Regional Aquaculture Center) Publication No. 4600.9p.

22. Mohan, J.A. (2011). Integrated control of water hyacinth using a retardant dose of glyphosate herbicide. PhD, Faculty of Science, University of the Witwatersrand.177p.

23. Olufayo, M.O. and Alade, O.H. (2012). Acute toxicity and histological changes in gills, liver and kidney of catfish, Heterobranchus bidorsalis exposed to cypermethrin concentration. African Journal of Agricultural Research 7(31):4453-4459.

24. PAN (Pesticide Action Network) (2010). Environmental effects of pesticides: An impression of recent scientific literature.14p.

25. Pauwels, J.M., Van Ranst, E., Verloo, M. and Mvondo Ze, A. (1992). Manuel de Laboratoire de pédologie. Publications Agricoles $N^{\circ} 28$. Bruxelles: AGCD.

26. Peeters, F.M., Van den Brink, P.J., Vlaming, J., Groenwold, J.G., Beltman, W.H.J. and Boesten, J.J.T.I. (2008). PRIMET version 2.0, manual and technical description. A Decision Support System for assessing Pesticide RIsks in the tropics to Man, Environment and Trade. Alterra-Report No 1648, Alterra, Wageningen, The Netherlands.

27. Pollino, C.A., Thomas, C.R. and Hart, B.T. (2012). Introduction to Models and Risk Assessment, Human and Ecological Risk Assessment: An International Journal, 18(1): 13-15.

28. R Core Team (2017). R: A language and environment for statistical computing. R Foundation for Statistical Computing, Vienna, Austria.URL https://www.R-project.org/. 
29. Rauf, A. and Javed, M. (2007). Copper toxicity to water and plankton in the river Ravi, Pakistan. International Journal of Agriculture and Biology 5:771-774.

30. Rissik, D., Van Senden, D., Doherty, M., Ingleton, T., Ajani, P., Bowling, L., Gibbs, M., Gladstone, M., Kobayashi, T., Suthers, I. and Froneman, W. (2009). Plankton-related environmental and waterquality issues. In ; Plankton: a guide to their ecology and monitoring for water quality, (ed). Suthers, I.M. and Rissik, D., CSIRO Publishing, Australia. 256p.

31. Sarwar, M. (2012). Insecticide Risk Exposes Threat to Aquatic Life in Surface Water Bodies and its Remedying. International Journal for Research in Physics, Chemistry \& Applied Science 2(7):12-20.

32. Schmolke, A., Thorbek, P., Chapman, P. and Grimm, V. (2010). Ecological models and pesticide risk assessment: current modeling practice. Environ Toxicol Chem 29:1006-1012.

33. Singh, N., Singh, I. Mukerjee, S. Gupta, V. T. Gajbhiye, P. K. Sharma, M. Goel, and P. Dureja. 2010. Metabolism of 14Cazoxystrobin in water at different $\mathrm{pH}$. Journal of Environmental Science and Health, Part B 45:123-127.

34. Souop, D. (2000). Obsolete pesticides stocks in Cameroon. In: OECDFAO-UNEP workshop in obsolete pesticide. 13-15 September 2000; Ms Anne LINDSAY, Alexandra, Virginia, USA. 67p.

35. Syan, H.S., Prasher, S.O., Pageau, D. and Singh, J. (2014). Dissipation and persistence of major herbicides applied in transgenic and non-transgenic canola production in Quebec. European Journal of Soil Biology 63:21-27.

36. Teló, G.M., Marchesan, E., Zanella, R., Limberger de Oliveira, M., Coelho, L.L. and Martins, M.L. (2015). Residues of Fungicides and Insecticides in Rice Field. Agronomy Journal107 (3): 851-863.

37. Wang, M. and Grimm, V. (2010). Population models in pesticide risk assessment: lessons for assessing population-level effects, recovery, and alternative exposure scenarios from modeling a small mammal. Environ. Toxicol. Chem. 29:1292-1300.

38. Zhang, W., Mu, S., Zhang, Y. and Chen, K. (2012). Seasonal and interannual variations of flow discharge from Pearl River into sea. Water Science and Engineering 5(4): 399-409. 